\title{
Genome Size and Karyotype Studies in Five Species of Lantana (Verbenaceae)
}

S. Brooks Parrish

Department of Environmental Horticulture, Gulf Coast Research and Education Center, University of Florida, IFAS, 14625 County Road 672, Wimauma, FL 33598

\section{Renjuan Qian}

Department of Environmental Horticulture, Gulf Coast Research and Education Center, University of Florida, IFAS, Wimauma, FL 33598; Zhejiang Institute of Subtropical Crops, 334 Xueshan Road, Wenzhou, Zhejiang 325005, China

\section{Zhanao Deng}

Department of Environmental Horticulture, Gulf Coast Research and Education Center, University of Florida, IFAS, 14625 County Road 672, Wimauma, FL 33598

Additional index words. chromosome number, chromosome morphology, cytogenetic analysis, ploidy, tetraploid

Abstract. Lantana species are an important component of the U.S. environmental horticulture industry. The most commonly produced and used species are $L$. camara and, on a smaller scale, L. montevidensis. Both were introduced to the United States from Central and/or South America. Lantana species native to the continental United States include $L$. canescens, L. depressa, L. involucrata, etc. and most of them have not been well exploited. This study was conducted to obtain information about somatic chromosome numbers, karyotypes, and genome size of these five species. Nuclear DNA content in these species ranged from $2.74 \mathrm{pg} / 2 \mathrm{C}$ (L. involucrata) to $6.29 \mathrm{pg} / 2 \mathrm{C}$ (L. depressa var. depressa). Four chromosome numbers were observed: $2 n=2 x=22$ in $L$. camara 'Lola' and 'Denholm White', $2 n=4 x=44$ in $L$. depressa var. depressa, $2 n=2 x=24$ in $L$. canescens and $L$. involucrata, and $2 n=3 x=36$ in $L$. montevidensis. Two basic chromosome numbers were observed: $x=11$ in $L$. camara and $L$. depressa var. depressa, and $x=12$ in $L$. canescens, $L$. involucrata, and $L$. montevidensis. Analysis of somatic metaphases resulted in formulas of $20 \mathrm{~m}+2 \mathrm{sm}$ for $L$. camara 'Lola' and 'Denholm White', $12 \mathrm{~m}+12 \mathrm{sm}$ for $L$. canescens, $44 \mathrm{~m}$ for $L$. depressa var. depressa, $10 \mathrm{~m}+14 \mathrm{sm}$ for $L$. involucrata, and $32 \mathrm{~m}+$ $4 \mathrm{sm}$ for $L$. montevidensis. Satellites were identified in all five species, but were associated with a different chromosome group in different species. $L$. depressa var. depressa had the longest total chromatin length $(146.78 \mu \mathrm{m})$ with a range of 1.88 to $4.41 \mu \mathrm{m}$ for individual chromosomes. The maximum arm ratio was observed in $L$. canescens, with a ratio of 2.5 in chromosome group 3. L. depressa var. depressa was the only species that had all of its centromeres located in the median region of the chromosome. The results show significant differences in nuclear DNA content, chromosome number, and karyotype among three native and two introduced lantana species and will help to identify, preserve, protect, and use native lantana species. The information will be helpful in assessing the ploidy levels in the genus by flow cytometry.

Received for publication 1 Dec. 2020. Accepted for publication 4 Jan. 2021.

Published online 4 February 2021.

This project was funded in part by the U.S. Department of Agriculture Hatch Project FLA-GCC-005507.

We are grateful to Jaroslav Doležel (Institute Experimental Botany, Olomouc, Czech Republic) for providing the rye and soybean seeds used in the flow cytometric analysis. We extend our appreciation to Alan Chamber, Tong Geon Lee, and Germán Miranda Sandoya for their critical review of this manuscript before its submission and for their valuable comments. R.Q. is a visiting scholar.

Z.D. is the corresponding author. E-mail: zdeng@uff. edu.

This is an open access article distributed under the CC BY-NC-ND license (https://creativecommons. org/licenses/by-nc-nd/4.0/). estimated at \$40 million a year (Wirth et al., 2004).

The genus Lantana contains 129 accepted species (The Plant List, 2013). L. camara is the most commonly cultivated species, with hundreds of cultivars around the world (Sanders, 2012). L. montevidensis is also a popular species, but with a smaller scale in production. Both species originated from Central and/or South America and have been introduced to more than 60 countries and islands around the globe (Day et al., 2003). These species are known to escape cultivation and invade natural and agricultural lands through their bountiful seed production and pollination (Florida Exotic Pest Plant Council, 2019; Henderson, 1969). For example, $L$. camara in Florida has invaded natural and agricultural land, and hybridized with a native species ( $L$. depressa) to the point where the native lantana has become an endangered species (Florida Department of Agriculture and Consumer Services, 2018). Similarly, $L$. camara has spread widely in Australia, India, South Africa, and other countries, and has caused substantial economic and ecological damage (Day et al., 2003). In Australia alone, L. camara has invaded 5,000,000 ha of land throughout coastal areas of Australia (Queensland Department of Agriculture and Fisheries, 2016). L. montevidensis has become an aggressive weed in Australia by taking over native grasslands during periods of drought (Weeds Australia, 2011). Although it has not yet been listed as a weed of national significance like $L$. camara, it does have potential and its use is restricted (Steppe et al., 2019). Considering the invasive potential of these lantana species, the environmental horticulture industry has been urged to produce and use more native and/or sterile lantana species (Hammer, 2004). Lantana species native to the continental United States include $L$. canescens, $L$. depressa, $L$. involucrata, etc. (Sanders, 2001). The genus Lantana is often split into four distinct sections: Calliorheas, Sarcolippia, Rytocamera, and Camara (Briquet, 1895; Day et al., 2003). Lantana camara and L. depressa are both categorized in the Camara section, whereas L. canescens, L. involucrata, and L. montevidensis fall under the Calliorheas section.

Cytological studies of lantana throughout the years have focused most attention on $L$. camara. Patermann (1938) was the first to report a chromosome number for the Lantana genus, identifying $L$. trifolia as $2 n=48$. Since then, a range of ploidy levels have been identified in L. camara, from $2 n=22$ to 55 with a base number of $x=11$ (Fedorov, 1969; Goldblatt, 1981; Natarajan and Ahuja, 1957; Ojha and Dayal, 1992; Raghavan and Arora, 1960; Sanders, 1987; Sen and Sahni, 1955; Singh, 1951; Sinha and Sharma, 1982, 1984; Spies, 1984; Spies and Stirton, 1982a, 1982b; Tandon and Chandi, 1955). Both triploid $(2 n=36)$ and tetraploid $(2 n=48)$ cytotypes of $L$. montevidensis have been reported in Australia (Henderson, 1969). Chromosome numbers have been reported for lantana 
Table 1. Nuclear DNA content and karyotype summary of six lantana selections.

\begin{tabular}{|c|c|c|c|c|c|c|c|c|c|}
\hline Species/cultivar & 2C DNA (pg) & 1Cx DNA (pg) & $\begin{array}{c}\text { Metaphases } \\
\text { observed }\end{array}$ & $\begin{array}{c}\text { Somatic } \\
\text { number }(2 n)\end{array}$ & $\begin{array}{c}\text { Basic } \\
\text { number }(n)\end{array}$ & $\begin{array}{l}\text { Ploidy } \\
\text { level }\end{array}$ & $\begin{array}{c}\text { Total karyotype } \\
\text { length }(\mu \mathrm{m})\end{array}$ & $\begin{array}{c}\text { Chromosome } \\
\text { length, range }(\mu \mathrm{m})\end{array}$ & $\begin{array}{l}\text { Satellite } \\
\text { group }\end{array}$ \\
\hline Lantana camara 'Lola' & $3.02 \pm 0.04 b^{z}$ & 1.52 & 40 & 22 & 11 & $2 x$ & $104.57 \pm 1.25$ & $3.31-6.18$ & 7 \\
\hline Lantana camara 'Denholm White' & $3.04 \pm 0.03 \mathrm{~b}$ & 1.52 & 42 & 22 & 11 & $2 x$ & $123.49 \pm 2.84$ & $4.30-6.93$ & 7 \\
\hline Lantana depressa var. depressa & $6.29 \pm 0.01 \mathrm{a}$ & 1.57 & 33 & 44 & 11 & $4 x$ & $146.78 \pm 1.80$ & $1.88-4.41$ & 6 \\
\hline Lantana canescens & $2.78 \pm 0.22 \mathrm{cde}$ & 1.39 & 36 & 24 & 12 & $2 x$ & $94.56 \pm 1.56$ & $2.13-5.59$ & 9 \\
\hline Lantana involucrata & $2.74 \pm 0.25 \mathrm{de}$ & 1.37 & 40 & 24 & 12 & $2 x$ & $78.99 \pm 3.26$ & $1.74-5.04$ & 9 \\
\hline Lantana montevidensis & $2.96 \pm 0.03 \mathrm{bcd}$ & 0.99 & 31 & 36 & 12 & $3 x$ & $104.50 \pm 0.60$ & $1.86-4.64$ & 2,10 \\
\hline
\end{tabular}

${ }^{\mathrm{z}}$ Means followed by the same letter are not significantly different by the Tukey-Kramer honestly significant difference test at the $5 \%$ level of significance.

species native to the United States- $L$. involucrata $(2 n=24,36)$, L. depressa $(2 n=22)$, and $L$. canescens $(2 n=24)$ (Natarajan and Ahuja, 1957; Raghavan and Arora, 1960; Sanders, 1987) — but no information is available on their karyotypes.

Flow cytometry has been used to determine polyploidy in lantana (Czarnecki and Deng, 2009; Czarnecki et al., 2014). To interpret ploidy accurately from relative or absolute nuclear DNA contents, it is essential to understand the variation of nuclear DNA content among plant species and establish proper references (Doležel et al., 2007). Nuclear DNA content is often expressed in picograms per $2 \mathrm{C}$ value or picograms per somatic cell (Greilhuber et al., 2005). 2C nuclear DNA content for L. camara $(2 n=22)$ was reported previously as $2.75 \mathrm{pg}$ (Ohri et al., 2004). Steppe et al. (2019) reported 2C nuclear DNA content for triploid and tetraploid forms of $L$. montevidensis measuring 2.80 to $2.85 \mathrm{pg} / 2 \mathrm{C}$ and $3.98 \mathrm{pg} / 2 \mathrm{C}$, respectively. Nuclear DNA content for other species and cultivars of lantana remains to be reported. Ojha and Dayal (1992) were the first to record chromosome measurements and classify lantana chromosomes based on size. The study classified chromosomes of $L$. camara, L. montevidensis, and L. fucata in India and used ideograms to visualize differences. Giemsa banding and fluorescence in situ hybridization have been used to analyze a tetraploid cultivar of L. camara (Brandão et al., 2007). However, a karyogram was not constructed and chromosome measurements were not recorded in the study, likely because of the low clarity of the chromosome spreads.

Much is known about the chromosome numbers of many lantana species, but the ability to visualize clear, well-stained metaphases has limited cytological analysis in lantana. The purpose of this study was to identify cytological features of three lantana species native to the United States and two introduced, cultivated species. The main objective was to obtain clear, darkly stained metaphase chromosome spreads of five species of lantana. Additional objectives were to produce karyotypes for each of the lantana selections and determine nuclear DNA content and its relationship with chromosome number. It is anticipated that information gathered from this study will help in the preservation of native lantana species and assist in the production of new cultivars through plant breeding.

\section{Materials and Methods}

Plant materials. Cuttings of L. canescens, $L$. involucrata, $L$. depressa var. depressa, $L$. montevidensis, L. camara 'Lola', and $L$. camara 'Denholm White' were taken from plants maintained at the University of Florida's Gulf Coast Research and Education Center, Wimauma, FL. Lantana plants were grown in 15-cm-diameter plastic containers filled with a commercial soilless mix (Fafard 2P mix; Florida Potting Soil, Orlando, FL). Plants were irrigated by hand daily and were fertilized with a controlled-release fertilizer (Osmocote, 15N-3.9P-10K, 5- to 6-month release at $21{ }^{\circ} \mathrm{C}$; The Scotts Company, Marysville, $\mathrm{OH}$ ) at $6.51 \mathrm{~kg} \cdot \mathrm{m}^{-3}$. Plants were grown under natural light in a temperaturecontrolled greenhouse set between $29.4{ }^{\circ} \mathrm{C}$ during the day and $21.1^{\circ} \mathrm{C}$ at night.

Nuclear DNA content determination. An Accuri C6 flow cytometer (BD Biosciences, San Jose, CA) at the University of Florida's Interdisciplinary Center for Biotechnology Research, Gainesville, FL, was used to determine nuclear DNA content. The protocol suggested by Doležel et al. (2007) was followed using both rye [Secale cereal 'Daňkovské' (16.19 pg/2C)] and soybean [Glycine max Merr. 'Polanka' (2.50 pg/2C)] as internal standards. One milliliter of cold LBO1 lysis buffer (Doležel et al., 2007) was added to a petri dish at room temperature, and $\approx 30 \mathrm{mg}$ of tender leaf tissue of lantana and either rye or soybean were chopped together using a fresh razor blade to release nuclei. The homogenate was filtered through a nylon mesh $(50 \mu \mathrm{m})$ into a loading tube, and $50 \mu \mathrm{L}$ of the DNA fluorochrome propidium iodide (Sigma-Aldrich; $1 \mathrm{mg} \cdot \mathrm{mL}^{-1}$ ) and RNase (Sigma-Aldrich; $1 \mathrm{mg} \cdot \mathrm{mL}^{-1}$ ) were added. The nuclei-containing solution was fed into the flow cytometer. Three biological replicates were analyzed with rye as the internal standard, and three biological replicates were analyzed with soybean as the internal standard. A minimum of 3000 nuclei were counted per run. Nuclear DNA content (in picograms per $2 \mathrm{C}$ value) was calculated according to Doležel et al. (2007): Sample DNA content $=$ Nuclear DNA content of internal standard ('Daňkovské' rye or 'Polanka' soybean) $\times$ (Mean fluorescence value of sample $\div$ Mean fluorescence value of internal standard). The DNA content estimations based on the two different standards were averaged together.

Chromosome counting. The cell wall degradation hypotonic method of Chen et al.
(1982) was used to prepare chromosome spreads. Before 10:00 AM, vigorously growing root tips $(1 \mathrm{~cm})$ were excised from lantana plants and treated in $0.002 \mathrm{M}$ 8-hydroxyquinoline for $3 \mathrm{~h}$ in the dark. Root tips were fixed in $200 \mu \mathrm{L}$ fixative solution ( 3 methanol : 1 acetic acid, v/v) for at least $2 \mathrm{~h}$. The fixed roots were rinsed three times in deionized water before a 1-mm section of the root tip was excised and macerated in an enzyme solution containing $2.5 \%$ cellulase and $2.5 \%$ pectinase for $2 \mathrm{~h} 30 \mathrm{~min}$ inside an incubator at $27{ }^{\circ} \mathrm{C}$. Macerated root tips were washed in deionized water for $10 \mathrm{~min}$ and then fixed in a fixative solution (3 methanol : 1 acetic acid, $\mathrm{v} / \mathrm{v}$ ) for $0.5 \mathrm{~h}$. Root tips were squashed in a drop of the fixative solution on a microscopic glass slide to disperse cells. The prepared slide was heated over an alcohol burner for a few seconds and stained with a $2.5 \%$ Giemsa solution for $10 \mathrm{~min}$. Stained glass slides were rinsed in distilled water, air-dried, and then observed using a BX41 microscope with an Olympus Q-color 5 camera (Olympus America Inc., Melville, NY). Darkly stained and well-spread chromosomes were photographed at $\times 1000$ magnification. A minimum of 30 cells were counted per selection.

Karyotyping and measurements. Karyograms of each cultivar/species were constructed using SmartType Karyotyper (Digital Scientific UK, Cambridge, England). Chromosome measurements were recorded from two cells per selection using ImageJ $1.52 \mathrm{~s}$ (U.S. National Institutes of Health, Bethesda, MD). Chromosome morphology was described using the ratio of long arm length to short arm length as described by Levan et al. (1964).

Statistical analysis. Analysis of variance was performed to determine the significant differences $(P \leq 0.05)$ among lantana selections in DNA content using JMP Pro 15.0.0 (SAS Institute, Cary, NC) with the TukeyKramer honestly significant difference procedure.

\section{Results and Discussion}

Nuclear DNA content. Nuclear DNA content calculations were consistent using both soybean and rye references. Nuclear DNA content ranged from $2.74 \mathrm{pg} / 2 \mathrm{C}$ ( $L$. involucrata, $2 n=24)$ to $6.26 \mathrm{pg} / 2 \mathrm{C}$ (L. depressa var. depressa, $2 n=44$ ) (Table 1). Standard deviation (SD) values for average DNA content in most of the samples were between 0.01 and $0.04 \mathrm{pg} / 2 \mathrm{C}$, but the SD values in two 


\begin{tabular}{|c|c|c|c|c|c|c|c|c|c|c|c|c|c|}
\hline \multirow[b]{2}{*}{ Species/cultivar } & \multicolumn{12}{|c|}{ Chromosome pairs } & \multirow[b]{2}{*}{ Arm ratio ${ }^{y}$ (range) } \\
\hline & $1^{\mathrm{z}}$ & 2 & 3 & 4 & 5 & 6 & 7 & 8 & 9 & 10 & 11 & 12 & \\
\hline Lantana camara 'Lola' & $\mathrm{m}$ & $\mathrm{m}$ & $\mathrm{m}$ & $\mathrm{m}$ & $\mathrm{m}$ & $\mathrm{m}$ & $\mathrm{sm}$ & $\mathrm{m}$ & $\mathrm{m}$ & $\mathrm{m}$ & $\mathrm{m}$ & & $1.05-1.93$ \\
\hline Lantana camara 'Denholm White' & $\mathrm{m}$ & $\mathrm{m}$ & $\mathrm{m}$ & $\mathrm{m}$ & $\mathrm{m}$ & $\mathrm{m}$ & $\mathrm{sm}$ & $\mathrm{m}$ & $\mathrm{m}$ & $\mathrm{m}$ & $\mathrm{m}$ & & $1.06-1.81$ \\
\hline Lantana depressa var. depressa & $\mathrm{m}$ & $\mathrm{m}$ & $\mathrm{m}$ & $\mathrm{m}$ & $\mathrm{m}$ & $\mathrm{m}$ & $\mathrm{m}$ & $\mathrm{m}$ & $\mathrm{m}$ & $\mathrm{m}$ & $\mathrm{m}$ & & $1.18-1.43$ \\
\hline Lantana canescens & $\mathrm{sm}$ & $\mathrm{m}$ & $\mathrm{sm}$ & $\mathrm{sm}$ & $\mathrm{sm}$ & $\mathrm{m}$ & $\mathrm{sm}$ & $\mathrm{m}$ & $\mathrm{m}$ & $\mathrm{m}$ & $\mathrm{m}$ & $\mathrm{m}$ & $1.21-2.06$ \\
\hline Lantana involucrata & $\mathrm{sm}$ & $\mathrm{m}$ & $\mathrm{sm}$ & $\mathrm{sm}$ & $\mathrm{sm}$ & $\mathrm{m}$ & $\mathrm{sm}$ & $\mathrm{sm}$ & $\mathrm{sm}$ & $\mathrm{m}$ & $\mathrm{m}$ & $\mathrm{m}$ & $1.20-2.39$ \\
\hline Lantana montevidensis & $\mathrm{sm}$ & $\mathrm{m}$ & $\mathrm{m}$ & $\mathrm{sm}$ & $\mathrm{m}$ & $\mathrm{m}$ & $\mathrm{m}$ & $\mathrm{m}$ & $\mathrm{m}$ & $\mathrm{m}$ & $\mathrm{m}$ & $\mathrm{m}$ & $1.27-2.10$ \\
\hline
\end{tabular}

${ }^{\mathrm{z}}$ Chromosome group number in karyotype.

${ }^{\mathrm{y}}$ Arm ratio $=$ Length of the long arm $\div$ Length of the short arm.

$\mathrm{m}=$ median region chromosomes (arm ratio, $>1.0$ and $<1.7) ; \mathrm{sm}=$ submedian region chromosomes $($ arm ratio, $>1.7$ and $<3.0$ ).

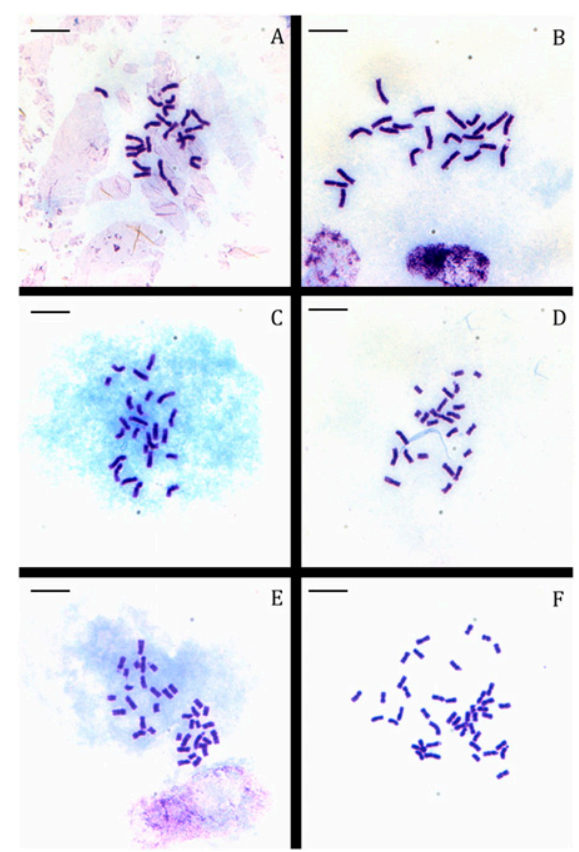

Fig. 1. Micrographs $(\times 1000)$ of somatic chromosomes observed in lantana root-tip cells stained in Giemsa. (A) Lantana camara 'Lola'. (B) Lantana camara 'Denholm White'. (C) Lantana canescens. (D) Lantana involucrata. (E) Lantana montevidensis. (F) Lantana depressa var. depressa. Scale bar $=10 \mu \mathrm{m}$.

samples (L. canescens and L. involucrata) were much greater $(0.25 \mathrm{pg})$ (Table 1$)$. The 2C DNA content of L. montevidensis differed by only $0.05 \mathrm{pg}$ from the amount reported by Steppe et al. (2019). Nuclear DNA content for $L$. camara differed from the previous report by Ohri et al. (2004) by $\approx 0.25 \mathrm{pg}$. This difference could be a combination of a different cultivar being used and, in the previous report, 2C DNA content was calculated from 4C DNA. This is the first report of nuclear DNA content for 'Lola', 'Denholm White', L. canescens, L. involucrata, and $L$. depressa var. depressa. Based on the ploidy level (discussed later), the nuclear DNA content per monoploid (1Cx) ranged from 0.99 to $1.57 \mathrm{pg}$ (Table 1 ). The variation observed in the $1 \mathrm{Cx}$ value among lantana species highlights the importance of using a reference sample from the same species when inferring ploidy level based on flow cytometer results or relative nuclear DNA contents.

Chromosome counting. Before this study, root-tip squashing followed by acetic car- mine staining was the primary method for observing lantana chromosomes (Czarnecki and Deng, 2009; Natarajan and Ahuja, 1957; Ojha and Dayal, 1992; Sanders, 1987). Although this method produced lantana metaphases clear enough for chromosome counting, it rarely resulted in lantana metaphases with a sufficient resolution or clarity for identifying major chromosomal features, such as centromeres, arms, and satellites, and for constructing reliable karyotypes. The cell wall degradation hypotonic method (Chen et al., 1982) used in this study produced many lantana metaphase spreads with excellent clarity. Major features of lantana chromosomes were clearly recognized (Fig. 1). It was relatively easy to produce dozens of metaphases with well-spread, darkly stained chromosomes for each sample in the five lantana species.

Examination of 222 metaphases revealed four chromosome numbers in these lantana species $(2 n=22,24,36$, and 44$)$ (Table 1$)$. In this study, the diploid version of $L$. involucrata $(2 n=24)$ was observed, confirming the chromosome number reported by Sanders (1987). The triploid cytotype of L. montevidensis was observed with a chromosome number of $2 n=36$, as previously reported by Henderson (1969). Chromosome numbers of $L$. camara, $L$. canescens, and $L$. depressa var. depressa also confirmed previous reports. These samples showed two base numbers ( $x=11$ or 12$)$, with $x=11$ in L. camara and $L$. depressa var. depressa, and $x=12$ in $L$. canescens, L. involucrata, and L. montevidensis.

It is interesting to note that $L$. canescens, L. involucrata, and L. montevidensis have a higher chromosome base number (12 vs. 11) but lower $1 \mathrm{Cx}$ values $(0.99-1.39$ vs. $1.52 \mathrm{pg})$ compared with L. camara 'Lola' and 'Denholm White' and L. depressa var. depressa. This may suggest that some chromosomes of L. canescens, L. involucrata, and L. montevidensis (in section Calliorheas) contain less DNA compared with their counterpart chromosomes in L. camara and L. depressa var. depressa (in section Camara).

Karyotyping. The lantana root-tip cell metaphases prepared in this study allowed clear identification of centromeres and satellites. Classification of chromosome groups by centromere location and relative size and further classification of groups by size yielded clear karyograms for each selection (Fig. 2). Chromosome satellites (secondary constrictions) were observed in each selection, but the group number of chromosomes bearing satellites varied, making them useful landmarks for identification of each species (Fig. 2, Table 1). The length of satellites ranged from $0.44 \mu \mathrm{m}$ in $L$. involucrata to $1.30 \mu \mathrm{m}$ in L. camara 'Denholm White', with an average length of $0.80 \mu \mathrm{m}$. Both cultivars of $L$. camara had one satellite on each chromosome in group 7. L. canescens and $L$. involucrata also had a distinguishable satellite on each chromosome in one group, but chromosome sizes placed them in group 9. $L$. depressa var. depressa had a satellite on each of the four chromosomes in group 6 of the karyogram.

In the study conducted by Brandão et al. (2007), satellites were visible in $L$. camara metaphase images, but low image quality prevented karyotyping and measurements. Ojha and Dayal (1992) showed satellites in one chromosome group in a triploid, tetraploid, and pentaploid of L. camara examined. The study did not identify any satellites in the diploid varieties analyzed, which could be the result of low-resolution images. L. montevidensis had satellites in two chromosome groups. Two of three chromosomes in group 2 had satellites and one of three chromosomes in group 10 had a satellite. This phenomenon could be the result of a diploid and tetraploid cross, where the satellites on chromosome group 2 originated in the tetraploid parent, and the satellite in chromosome 10 was contributed by the diploid parent. Further investigation into the lineage of the triploid $L$. montevidensis is needed to determine the source of the satellite groups.

Chromosome measurements. The largest chromosome recorded had a length of $6.93 \mu \mathrm{m}$ in L. camara 'Denholm White' and this cultivar had the largest average chromosome length of $5.61 \mu \mathrm{m}$. The smallest average chromosome length was $2.90 \mu \mathrm{m}$ and was found in the triploid L. montevidensis. It is of interest to note that $L$. montevidensis recorded the lowest nuclear DNA content per basic chromosome number $(1 \mathrm{Cx})$ as well. Total karyotype length was the lowest in the diploid L. involucrata at $78.99 \mu \mathrm{m}$ and greatest in tetraploid L. depressa var. depressa at $146.78 \mu \mathrm{m}$. A previous study reported a range of lantana chromosome length of 1.37 to $4 \mu \mathrm{m}$ (Ojha and Dayal, 1992). These values were much smaller than those reported in this study; it remains to be determined whether different pretreatment methods and plant 


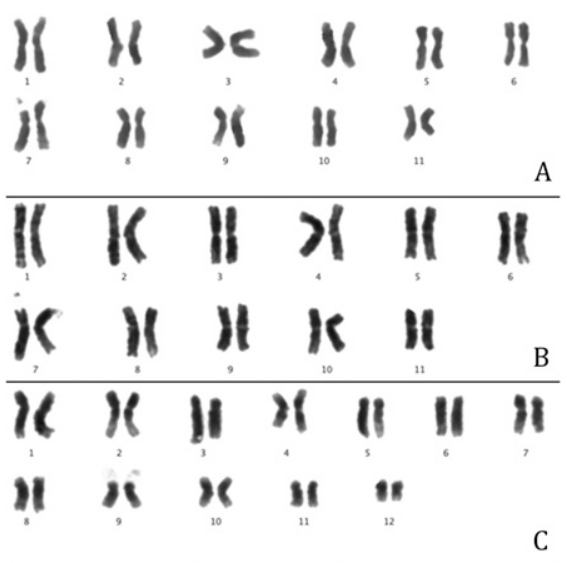

II

D

\section{III (it III Ift 111 in iI

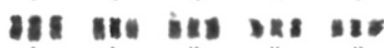 \\ E

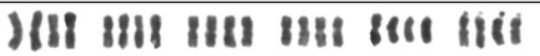

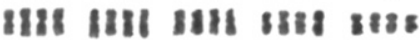

Fig. 2. Karyotypes of six lantana selections. (A) Lantana camara 'Lola'. (B) Lantana camara 'Denholm White'. (C) Lantana canescens. (D) Lantana involucrata. (E) Lantana montevidensis. (F) Lantana depressa var. depressa.

tissues used [leaf tips in Ojha and Dayal (1992) vs. root tips in our study] might have contributed to this variation. Total chromatin length provided more drastic differences between species of the same ploidy when compared with DNA content. This information could be valuable in species or cultivar identification studies where DNA content and the presence of satellites are not differentiable features.

The chromosomes have been designated according to Levan et al. (1964), i.e., median point $[\mathrm{M}$, arm ratio $(\mathrm{r})=1.0]$, median region $(\mathrm{m}, \mathrm{r}>1.0$ and $\leq 1.7)$, submedian region $(\mathrm{sm}$, $\mathrm{r}>1.7$ and $\leq 3.0$ ), subterminal region (st, $\mathrm{r}>$ 3.0 and $\leq 7.0)$, terminal region $(\mathrm{t}, \mathrm{r}>7.0)$, and terminal point $(\mathrm{T}, \mathrm{r}=\infty)$. Lantana involucrata had the most chromosome sm groups, with more than half of its centromeres located in sm (Table 2). A recognizable feature of the L. camara species is the sm chromosomes in group 7 with obvious satellites, which might be useful for detecting interspecific hybrids originating from crosses involving $L$. camara. Both $L$. canescens and L. involucrata have many more sm chromosomes in addition to the presence of satellites. Lantana depressa var. depressa had all its centromeres located in $\mathrm{m}$. The differences observed in the size and arrangement of chromosomes in the karyotypes of these five species may suggest the variation in gene arrangement and composition that differentiates the phenotypes of these species (Stebbins, 1971). Because of the large genome size of lantana, sequencing data have yet to be published, but are needed to investigate the variation in gene composition of these different species. Toward this, the combination of this research with $L$. camara transcriptomes already published (Peng et al., 2019; Shah et al., 2020) may aid in future assembly and annotation of the lantana genome.

Our results revealed significant variation in chromosome morphology and nuclear DNA content among the five lantana species accessed. This is the first report of nuclear DNA content for the three U.S. native lantana species and the first karyotypes constructed for each species except $L$. camara. The chromosome squash protocol presented will allow for further cytological investigation into other lantana species and cultivars. Nuclear DNA content data will provide references for ploidy analysis of breeding lines and unknown plants.

\section{Literature Cited}

Brandão, A.D., L.F. Viccini, F.R.G. Salimena, A.L.L. Vanzela, and S.M.R. Pimentel. 2007. Cytogenetic characterization of Lippia alba and Lantana camara (Verbenaceae) from Brazil. J. Plant Res. 120:317-321, doi: 10.1007 s10265-006-0041-4.

Briquet, J. 1895. Verbenaceae, p. 132-182. In: A. Engler and K. Prantl (eds.). Die natürlichen Pflanzenfamilien 4:3a. Wilhelm Engelmann, Leipzig, Germany.

Chen, R.Y., W.Q. Song, and X.L. Li. 1982. Wall degradation hypotonic method of preparing chromosome samples in plants and its significance in the cytogenetics. Acta Genet. Sin. 9(2):151-159.

Czarnecki, II, D.M., and Z. Deng. 2009. Occurrence of unreduced female gametes leads to sexual polyploidization in Lantana. J. Amer. Soc. Hort. Sci. 134:560-566, doi: 10.21273/ JASHS.134.5.560

Czarnecki, II, D.M., A.J. Hershberger, C.D. Robacker, D.G. Clark, and Z. Deng. 2014. Ploidy levels and pollen stainability of Lantana camara cultivars and breeding lines. HortScience 49:1271-1276, doi: 10.21273/HORTSCI. 49.10.1271

Day, M., C.J. Wiley, J. Playford, and M.P. Zalucki. 2003. Lantana: Current management status and future prospects. Austral. Ctr. Intl. Agr. Res., Canberra, Australia, doi: 10.22004/AG. ECON.114054.

Doležel, J., J. Greilhuber, and J. Suda. 2007. Estimation of nuclear DNA content in plants using flow cytometry. Nat. Protoc. 2:2233-2244, doi: 10.1038/nprot.2007.310.

Fedorov, A. 1969. Chromosome numbers of flowering plants. Komarov Bot. Inst., Leningrad, Russia.

Florida Department of Agriculture and Consumer Services. 2018. Endangered, threatened and commercially exploited species information. 7 May 2020. <https://www.fdacs.gov/Divisions-Offices/ Plant-Industry/Bureaus-and-Services/EntomologyNematology-Plant-Pathology/Botany/Florida-sEndangered-Plants/Endangered-Threatenedand-Commercially-Exploited-Plants-of-Florida $>$.
Florida Exotic Pest Plant Council. 2019. Florida Exotic Pest Plant Council's 2019 list of invasive plant species. 7 May 2020. <https://www.fleppc.org/list/ list.htm>.

Goldblatt, P. 1981. Index to plant chromosome numbers for 1975-1978. Monogr. Systematic Bot. Missouri Bot. Garden 5, doi: 10.2307/ 2806772.

Greilhuber, J., J. Doležel, M.A. Lysák, and M.D. Bennett. 2005. The origin, evolution and proposed stabilization of the terms 'genome size' and 'c-value' to describe nuclear DNA contents. Ann. Bot. 95:255-260, doi: 10.1093/aob/ mci019.

Hammer, R.L. 2004. The lantana mess: A critical look at the genus in Florida. The Palmetto 23(1):21-23.

Henderson, R.J.F. 1969. A cytological study of Lantana montevidensis (Spreng.). Briq. Contrib. Queensland Herbarium 3:1-4.

Levan, A., K. Fredga, and A.A. Sandberg. 1964. Nomenclature for centromeric position on chromosomes. Hereditas 52:201-220, doi: 10.1111/j.1601-5223.1964.tb01953.x.

Natarajan, A.R. and M.R. Ahuja. 1957. Cytotaxonomical studies in the genus Lantana. J. Indian Bot. Soc. 36:35-45.

Ohri, D., A. Bhargava, and A. Chatterjee. 2004 Nuclear DNA amounts in 112 species of tropical hardwoods: New estimates. Plant Biol. 6.555-561, doi: $10.1055 / \mathrm{s}-2004-821235$.

Ojha, B. and N. Dayal. 1992. Cytological investigations in the genus Lantana in India. Cytologia 57:9-13, doi: 10.1508/cytologia. 57.9.

Patermann, T. 1938. p. 324. In: C.D. Darlington and A.P. Wylie (eds.). Chromosome atlas of flowering plants, 2nd ed. George Allen and Unwin Ltd., London, England.

Peng, Z., K. Bhattarai, S. Parajuli, Z. Cao, and Z. Deng. 2019. Transcriptome analysis of young ovaries reveals candidate genes involved in gamete formation in Lantana camara. Plants 8(263):1-16, doi: 10.3390/plants8080263.

Queensland Department of Agriculture and Fisheries. 2016. Lantana fact sheet. 7 May 2020. <https:// www.business.qld.gov.au/industries/farms-fishingforestry/agriculture/land-management/healthpests-weeds-diseases/weeds-diseases/invasiveplants/restricted/lantana $>$

Raghavan, R.S. and C.M. Arora. 1960. Morphological and cytological studies in the genus Lantana L. Bul. Bot. Surv. India 2:299-303, doi: 10.20324/ nelumbo\%2Fv2\%2F $1960 \% 2 \mathrm{~F} 76601$.

Sanders, R.W. 1987. Taxonomic significance of chromosome observations in Caribbean species of lantana (Verbenaceae). Amer. J. Bot. 74:914 920, doi: 10.1002/j.1537-2197.1987.tb08695.x.

Sanders, R.W. 2001. The genera of Verbenaceae in the southeastern United States. Harv. Pap. Bot. 5:303-358. <https://www.jstor.org/stable/ 41761611>

Sanders, R.W. 2012. Taxonomy of Lantana Sect. Lantana (Verbenaceae): II. Taxonomic revision. J. Bot. Res. Inst. Tex. 6:403-441. <https:// www.jstor.org/stable/41972430>

Schoellhorn, R. 2004. Lantana: Summer color that's tough as nails. Greenhouse Prod. News 14(3):14-16.

Sen, N.K. and V.M. Sahni. 1955. Triploid, tetraploid, and pentaploid Lantana. Sci. Cult. 20:558-559.

Shah, M., H.F. Alharby, K.R. Hakeem, N. Ali, I.U. Rahman, M. Munawar, and Y. Anwar. 2020. De novo transcriptome analysis of Lantana camara L. revealed candidate genes involved in phenylpropanoid biosynthesis pathway. Scientific Rpt. 10:13726 , doi: 10.1038/s41598-020-70635-5. 
Singh, B. 1951. Chromosome numbers in some flowering plants. Curr. Sci. 20:105.

Sinha, S. and A. Sharma. 1982. Polyploidy in Lantana camara L. Proc. Kew Chromosome Conf. Kew, England.

Sinha, S. and A. Sharma. 1984. Chromosome studies in Lantana camara L.: Distribution of ploidy levels in relation to environmental conditions. Perspective Cytol. Genet. 4:491-494.

Spies, J.J. 1984. A cytotaxonomic study of Lantana camara (Verbenaceae) from South Africa. S. Afr. J. Bot. 3:231-250, doi: 10.1016/S00224618(16)30034-1.

Spies, J.J. and C.H. Stirton. 1982a. Chromosome numbers of southern African plants. J. Soc. African Bot. 48:21-22.
Spies, J.J. and C.H. Stirton. 1982b. Meiotic studies of some South African cultivars of Lantana camara (Verbenaceae). Bothalia 14:101-111, doi: 10.4102/ABC.V14I1.1148.

Stebbins, G.L. 1971. Chromosomal evolution in higher plants. Edward Arnold, London, UK.

Steppe, C., S.B. Wilson, Z. Deng, K. Druffel, and G.W. Knox. 2019. Morphological and cytological comparison of eight varieties of trailing lantana (Lantana montevidensis) grown in Florida. HortScience 54:2134-2138, doi: 10.21273/HORTSCI14443-19.

Tandon, S.L. and A.S. Chandi. 1955. Basic chromosome number in Lantana camara L. Curr. Sci. 24:124-125.
The Plant List. 2013. The Plant List: Version 1.1. 7 May 2020. <http://www.theplantlist.org/tp11.1/ search?q=lantana $>$.

Weeds Australia. 2011. Lantana montevidensis (Spreng.) Briq. 31 Dec. 2020. <https://profiles. ala.org.au/opus/weeds-australia/profile/Lantana\% 20montevidensis $>$.

Winder, J.A. 1980. Factors affecting the growth of lantana in Brazil. Univ. of Reading, Berkshire, UK, PhD Diss.

Wirth, F.F., K.J. Davis, and S.B. Wilson. 2004. Florida nursery sales and economic impacts of 14 potentially invasive ornamental plant species. J. Environ. Hort. 22:12-16, doi: 10.24266/0738-2898-22.1.12. 